\title{
PENGARUH RELAKSASI PROGRESIF TERHADAP PENURUNAN PERILAKU KEKERASAN PADA PASIEN SKIZOFRENIA DI RUMAH SAKIT JIWA DAERAH KLATEN
}

\author{
Suryanti, Dwi Ariani \\ Kementerian Kesehatan Politeknik Kesehatan Surakarta Jurusan Keperawatan
}

\begin{abstract}
Violent Behavior, Schizophrenia, Progressive Relay Therapy. Management or treatment of violent behavior is necessary and can be done in three ways, namely prevention programs, anticipation and restraint. Progressive relaxation is part of the anticipatory program. The progressive relaxation technique is to focus on a muscle activity, by identifying the tense muscles and then decreasing the tension by performing relaxation techniques to get relaxed feelings (Murphy, 1996). The purpose of this study is to determine the effect of progressive relaxation on the risk of violent behavior in patients with schizophrenia RSJD Klaten. The type of research is Quasi experiment with research design using One Group Pre and Post test Design. Sampling using non probability sampling technique by purposive sampling which amounted to 30 respondents in RSJD Klaten. Sample is done pre test fill out questionnaire BPRS (General Response Function Adaptif) which include behavioral response, verbal response, emotional response, and physical response with scale 1-14 .. Data analysis used is Paired t-test with the help of computer SPSS for Windows version 18.0. The results of research on progressive relaxation implant dillakuakn in RS Klaten Klaten, after analyzed with bivariate showed that there is a decrease of average between before and after given progressive relaxation action from before action 2.07 to after action 1.63 ( $t$ count 0.44 ) and $P$ value $0,000<\alpha(0.05)$. Interpretation of this research that progressive relaxation therapy is very influential in reducing the level of perilakukan violence in schizophrenic patients.
\end{abstract}

Keywords: Violent Behavior, Schizophrenia, Progressive Relay Therapy

\begin{abstract}
Abstrak: Perilaku Kekerasan, Skizofrenia, Terapi Relakasasi Progresif. Penatalaksanaan atau penanganan perilaku kekerasan sangat diperlukan dan dapat dilakukan dengan tiga cara, yaitu program pencegahan, antisipasi dan pengekangan. Relaksasi progresif merupakan bagian dari program antisipasi. Teknik relaksasi progresif adalah memusatkan perhatian pada suatu aktifitas otot, dengan mengidentifikasi otot yang tegang kemudian menurunkan ketegangan dengan melakukan teknik relaksasi untuk mendapatkan perasaan relaks (Murphy, 1996). Tujuan penlitian ini adalah untuk mengetahui Pengaruh Relaksasi Progresif Terhadap Resiko Penurunan Perilaku Kekerasan Pada Pasien Skizofrenia RSJD Klaten. Jenis penelitian adalah Quasi eksperimen dengan design penelitian menggunakan One Group Pre and Post test Design. Pengambilan sampel dengan menggunakan teknik non probability sampling dengan cara purposive sampling yang berjumlah 30 responden di RSJD Klaten. Sample dilakukan pre test mengisi angket BPRS (Respon Umum Fungsi Adaptif) yang meliputi respon perilaku, respon verbal, respon emosi, dan respon fisik
\end{abstract}


dengan skala 1-14.. Analisa data yang digunakan adalah Paired t-test dengan bantuan komputer SPSS for Windows versi 18,0. Hasil penelitian tentang pengaaruh relaksasi progresif yang dillakuakn di RSJD Klaten, setelah dianalisa dengan bivariat menunjukkan bahwa ada penurunan rerata antara sebelum dan sesudah diberi tindakan relaksasi progresif dari sebelum tindakan 2,07 menjadi setelah tindakan 1,63 (t hitung $0,44)$ dan $\mathrm{P}$ value $0,000<\alpha(0,05)$. Interpretasi penelitian ini bahwa terapi relaksasi progresif sangat berpengaruh dalam menurunkan tingkat perilakukan kekerasan pada pasien skizofrenia.

Kata Kunci: Perilaku Kekerasan, Skizofrenia, Terapi Relakasasi Progresif

\section{PENDAHULUAN}

Kehidupan manusia dewasa ini yang semakin sulit dan kompleks serta semakin bertambahnya stressor psikososial akibat budaya masyarakat modern yang cenderung lebih sekuler, menyebabkan manusia tidak dapat menghindari tekanan-tekanan hidup yang mereka alami. Kondisi kritis ini membawa dampak terhadap peningkatan kualitas maupun kuantitas penyakit mentalemosional manusia. Salah satu dampak negative dari penyakit mental-emosional adalah perilaku kekerasan (Hidayati (2000) dalam Nurjanah (2004).

Perilaku kekerasan adalah suatu keadaan dimana seseorang melakukan tindakan yang dapat membahayakan secara fisik baik terhadap diri sendiri, orang lain, maupun lingkungan.

Perilaku kekerasan dianggap sebagai suatu akibat yang ekstrim dari rasa marah atau ketakutan yang mal adaptif (panik). Perilaku agresif dan perilaku kekerasan itu sendiri sering dipandang sebagai suatu dimana agresif verbal di suatu sisi dan perilaku kekerasan (violence) di sisi yang lain.

Penatalaksanaan atau penanganan perilaku kekerasan sangat diperlukan dan dapat dilakukan dengan tiga cara, yaitu program pencegahan, antisipasi dan pengekangan. Relaksasi progresif merupakan bagian dari program antisipasi. Teknik relaksasi progresif adalah memusatkan perhatian pada suatu aktifitas otot, dengan mengidentifikasi otot yang tegang kemudian menurunkan ketegangan dengan melakukan teknik relaksasi untuk mendapatkan perasaan relaks (Murphy, 1996).

Berdasarkan latar belakang diatas penulis tertarik untuk meneliti tentang Pengaruh relaksasi progresif terhadap penurunan Resiko perilaku kekerasan Pada Pasien Skizofrenia di RSJD Klaten.

Schizofrenia merupakan suatu sindrome klinis atau proses penyakit yang mempengaruhi kognisi, persepsi, emosi, perilaku, dan fungsi sosial, tetapi schizofrenia mempengaruhi setiap individu dengan cara yang berbeda. Derajat gangguan pada fase akut atau fase psikotik dan fase kronis atau fase jangka panjang sangat bervariasi diantara individu (Videbeck, 2008).

Perilaku kekerasan adalah suatu keadaan dimana seseorang melakukan tindakan yang dapat membahayakan secara fisik baik terhadap diri sendiri, orang lain, maupun lingkungan.

Dalam keperawatan, katagori pasien perilaku kekerasan dibuat dengan skor RUFA (Respons Umum Fungsi Adaptif)/ GAFR (General Adaptive Function 
Response) yang merupakan modifikasi dari skor GAF. Sedangkan untuk mengetahui perkembangan perilaku kekerasan menggunakan skala BPRS (the Brief Psychiatric Rating Scale), karena keperawatan menggunakan pendekatan respons manusia dalam memberikan asuhan keperawatan sesuai dengan fungsi respons yang adaptif.

Relaksasi adalah satu teknik dalam terapi perilaku untuk mengurangi ketegangan dan kecemasan. Teknik ini dapat digunakan oleh pasien tanpa bantuan terapis dan mereka dapat menggunakannya untuk mengurangi ketegangan dan kecemasan yang dialami sehari-hari di rumah.

Teknik relaksasi progresif adalah memusatkan perhatian pada suatu aktifitas otot, dengan mengidentifikasi otot yang tegang kemudian menurunkan ketegangan. Strategi pencegahan antara lain melalui self awarenness perawat, pendidikan kesehatan, dan latihan asertif. Strategi antisipasi, terdiri dari : tekhnik komunikasi, perubahan lingkungan, perilaku, dan pemberian obat antipsikotik. Strategi pengekangan yang terdiri dari : tindakan manajemen krisis, pengikatan dan pembatasan gerak.

Ketiga strategi tersebut digunakan sebagai pendekatan dalam menguraikan tindakan keperawatan perilaku kekerasan yang akan diberikan pada penanganan perilaku kekerasan.

\section{METODE PENELITIAN}

Penelitian ini menggunakan metode "quasi experiment pre-post test with control group" dengan intervensi terapi musik pada tanggal 1 Mei sampai dengan 8 Juni 2009.

Sampel penelitian ini adalah klien Skizoprenia yang mengalami perilaku kekerasan dengan kriteria inklusi sebagai berikut : usia 18 - 55 tahun; alasan dirawat : klien dengan perilaku kekerasan; klien (keluarga) bersedia jadi responden ; hari kedua perawatan. Sampel berjumlah 80 orang, yang diambil dengan metode "Total Sampling”.

Penelitian dilakukan untuk menganalisa perubahan penurunan perilaku kekerasan sebelum dan sesudah perlakuan terapi musik serta membandingkan antara kelompok yang mendapatkan terapi generalis dan terapi musik dengan kelompok yang hanya mendapatkan terapi generalis. Setiap kelompok berjumlah 40 orang. Pada kelompok yang mendapat terapi musik dilakukan pertemuan sebanyak 4 sesi dalam rentang waktu 4 hari.

Perilaku kekerasan yang meliputi respon fisik, respon kognitif, respon perilaku dan respon sosial diukur dengan menggunakan kuesioner, observasi, dan pemeriksaan fisik serta dianalisis menggunakan dependent t-test, independent t-test, chi-square dan regresi liniear ganda dengan tampilan dalam bentuk tabel dan distribusi frekwensi.

\section{HASIL PENELITIAN}

Penelitian ini dilaksanakan tanggal 1 Mei sampai 8 Juni 2009, di Rumah Sakit Jiwa Daerah Surakarta terdapat 80 klien yang terdiri dari 40 klien mendapatkan terapi generalis dan 40 klien terapi musik dengan kelompok yang hanya mendapat terapi generalis. Adapun hasil penelitian sebagi berikut :

Hasil analisis menunjukan bahwa dari 80 klien rerata umur 31,30 tahun dengan umur termuda 18 tahun dan tertua 52 tahun. Sedangkan rerata frekwensi perawatan sebanyak 2,88 kali dengan jumlah perawatan yang terendah 1 kali 
dan tertinggi frekwensiperawatan perawatannya 10 kali. Rerata lama sakit 4,46 tahun dengan lama sakit seluruh responden yang terpendek 0,1 tahun dan yang terlama sakit 26 tahun. Demikian juga dari hasil ini pada alpha 5\% didapatkan adanya kesetaraan baik untuk umur, frekwensi perawatan dan lama menderita gangguan jiwa antara kelompok yang mendapatkan terapi generalis dan terapi musik dengan kelompok yang hanya mendapat terapi generalis (pvalue $>0,05$ ).

Hasil analisis terhadap proporsi klien yang berjenis kelamin laki-laki lebih banyak 68,8\% (55) dari perempuan. Pada pendidikan terbanyak SLTP dan SMU masing-masing 26 orang $(32.5 \%)$, sedangkan untuk proporsi tidak bekerja lebih banyak ( 62,5\% /50) dari pada yang bekerja. Proporsi klien tidak kawin lebih banyak kawin $(63,8 \% / 51)$ dari pada yang kawin. Demikian juga dari hasil ini pada alpha 5\% didapatkan adanya kesetaraan baik pada jenis kelamin, pendidikan, pekerjaan dan staus perkawinan antara kelompok yang mendapatkan terapi generalis dan terapi musik dengan kelompok yang hanya mendapat terapi generalis (pvalue > 0,05).

Hasil analisis perilaku kekerasan sebelum intervensi terapi musik memiliki rerata total respon fisik dengan skor 8,05, respon kognitif dengan skor 14,86 respon perilaku dengan skor 10,91 respon komposit dengan skor 35,81. Sedangkan hasil rerata pada kelompok yang mendapatkan terapi generalis dan terapi musik dengan kelompok yang hanya mendapat terapi generalis, sebelum intervensi terapi musik pada pada alpha $5 \%$ didapatkan adanya kesetaraan. Didapatkan pada respon fisik nilai $\mathrm{P}=$ 0,321 , respon kognitif nilai $\mathrm{P}=0,678$, respon perilaku nilai $\mathrm{P}=0,215$ respon sosial nilai $\mathrm{P}=0,823$, respon komposit nilai $\mathrm{P}=0,606$ berarti pada alpha $5 \%$ terlihat perilaku kekerasan antara kedua kelompok setara.

Hasil analisis disimpulkan pada alpha $5 \%$ didapatkan adanya penurunan perilaku kekerasan secara bermakna ( $p$ value 0,000 ), pada respon fisik skor ini turun sebesar 2,58, respon kognitif skor ini turun sebesar 6,80, pada respon perilaku skor ini turun sebesar 8,86, respon sosial skor ini turun sebesar 4,30, respon komposit skor ini turun sebesar 16,88 pada kelompok yang mendapatkan terapi generalis dan terapi musik. Demikian juga pada kelompok yang hanya mendapatkan terapi generalis pada alpha $5 \%$ didapatkan adanya penurunan perilaku kekerasan secara bermakna ( $p$ value 0,000 ), pada respon fisik skor ini turun sebesar 2,18 respon kognitif skor ini turun sebesar 4,72 pada respon perilaku skor ini turun sebesar 4,30, respon sosial skor ini turun sebesar 2,70, respon komposit skor ini turun sebesar 11,97.

Hasil analisis diperoleh bahwa pada alpha $5 \%$ didapatkan adanya penurunan rerata perilaku kekerasan secara bermakna pada kelompok mendapatkan terapi generalis dan terapi musik dalam respon fisik lebih rendah sebesar $-0,75$ ( $\mathrm{p}$ value 0,003), dalam respon kognitif lebih rendah sebesar $-2,35$ (p value 0,001) dalam respon perilaku lebih rendah sebesar $-1,65$ ( $\mathrm{p}$ value 0,000 ) dalam respon sosial lebih rendah sebesar $-2,02$ ( $\mathrm{p}$ value 0,000)a dalam respon komposit lebih rendah sebesar -5,78 (p value 0,000). Berdasarkan hasil uji statistik dapat disimpulkan penurunan respon perilaku kekerasan baik respon fisik, respon kognitif, respon perilaku, respon sosial dan respon komposit 
menunjukan lebih rendah secara bermakna sesudah perlakuan antara kelompok mendapatkan terapi generalis dan terapi musik dengan kelompok yang hanya mendapatkan terapi generalis ( $\mathrm{p}$ value $<0.005$ ).

Faktor-faktor yang berkontribusi terhadap respon perilaku kekerasan

Hasil analisis menunjukkan bahwa Terapi Musik dan jenis kelamin berhubungan dengan respon komposit (respon kognitif, perilaku, sosial).Terapi musik ( $p$ value $0,004)$ dan jenis kelamin ( $p$ value 0,001 ). Hubungan Terapi Musik dan jenis kelamin dengan respon fisik menunjukkan ada hubungan/ hubungan sedang $(\mathrm{R}=0,465)$. Terapi musik dan jenis kelamin mempunyai peluang sebesar 21,7 $\%$ terhadap pernurunan respon komposit. Sedangkan karakteristik lainnya yaitu usia, frekwensi perawatan, lama gangguan jiwa, pendidikan, pekerjaan, status perkawinan, tidak berpeluang terhadap penurunan perilaku kekerasan.

\section{PEMBAHASAN}

Hasil analisis menunjukkan bahwa Terapi Musik dan jenis kelamin berhubungan dengan respon kognitif. Terapi musik ( $p$ value 0,012 : alpha 0,05 ) dan jenis kelamin ( $p$ value 0,000 : alpha $0,05)$. Hubungan Terapi Musik dan jenis kelamin dengan respon kognitif menunjukkan ada hubungan/ hubungan kuat $(\mathrm{R}=0,501)$. Terapi musik dan jenis kelamin mempunyai peluang sebesar 25,1 $\%$ terhadap pernurunan respon kognitif.
Tabel 1

Analisis Kesetaraan Perilaku Kekerasan Sebelum Pelaksanaan Terapi Musik di RSJD

\begin{tabular}{|c|c|c|c|c|c|}
\hline Variabel & Kelompok & $\mathrm{N}$ & Mean & SD & $P$ value \\
\hline Respon & Intervensi & 40 & 7,88 & 1.7 & 0,321 \\
\hline Fisik & Kontrol & 40 & 8,23 & $\begin{array}{l}4 \\
1,3 \\
7\end{array}$ & \\
\hline Respon & Intervensi & .0 & 4,73 & 2,89 & ,678 \\
\hline kognitif & Kontrol & 0 & 5,00 & 3,00 & \\
\hline Respon & Intervensi & $\begin{array}{l}0 \\
0\end{array}$ & 0,53 & $\begin{array}{l}2,78 \\
277\end{array}$ & ,215 \\
\hline $\begin{array}{l}\text { Respon } \\
\text { sosial }\end{array}$ & $\begin{array}{l}\text { Intervensi } \\
\text { Kontrol }\end{array}$ & $\begin{array}{l}.0 \\
0\end{array}$ & $\begin{array}{l}0,13 \\
, 95\end{array}$ & $\begin{array}{l}3,37 \\
3,59\end{array}$ & ,823 \\
\hline $\begin{array}{l}\text { Komposit } \\
\text { (Kognitif, } \\
\text { Peri } \\
\text { laku, } \\
\text { Sosial) }\end{array}$ & $\begin{array}{l}\text { Intervensi } \\
\text { Kontrol }\end{array}$ & $\begin{array}{l}0 \\
.0\end{array}$ & $\begin{array}{l}5,38 \\
6,25\end{array}$ & $\begin{array}{l}7,65 \\
7,47\end{array}$ & ,606 \\
\hline
\end{tabular}

Tabel 2

Analisis Perbedaan Perilaku Kekerasan Sebelum dan Sesudah Pelaksanaan Terapi Musik di RSJD

\begin{tabular}{lcccc}
\hline Kelp. Intervensi & $\mathrm{N}$ & Mean & SD & P value \\
\hline Respon Fisik & & & & \\
Sebelum & 40 & 7,88 & 1,74 & 0,000 \\
Sesudah & 40 & 5,30 & 0,65 & \\
Selisih & & 2,58 & & \\
\cline { 2 - 5 } Respon kognitif & & & & \\
Sebelum & 40 & 14,73 & 2,89 & 0,000 \\
Sesudah & 40 & 7,93 & 1,94 & \\
$\quad$ Selisih & & 6,80 & & \\
\cline { 2 - 5 } Respon perilaku & & & & \\
Sebelum & 40 & 10,53 & 2,78 & 0,000 \\
Sesudah & 40 & 5,35 & 0,77 & \\
$\quad$ Selisih & & 8.86 & & \\
\cline { 2 - 5 } Respon sosial & \multicolumn{5}{c}{10,13} & 3,37 & 0,000 \\
Sebelum & 40 & 5,23 & 0,58 & \\
Sesudah & 40 & 5,30 & & \\
$\quad$ Selisih & & & & \\
\cline { 2 - 5 } Komposit & & & & \\
(Kognitif & & & & \\
Perilaku , Sosial) & 40 & 35,38 & 7,65 & 0,000 \\
Sebelum & 40 & 18,50 & 251 & \\
Sesudah & & 16,88 & & \\
$\quad$ Selisih & & & & \\
\hline
\end{tabular}


Tabel 3

Analisis Selisih Penurunan Perilaku Kekerasan Pada Kelompok Intervensi dan Kelompok Kontrol di RSJD Surakarta

\begin{tabular}{lllll}
\hline Variabel & Kelompok & $\mathrm{n}$ & $\begin{array}{l}\text { Selisih } \\
\text { Mean }\end{array}$ & $\begin{array}{c}P \\
\text { value }\end{array}$ \\
\hline Respon & Intervensi & 40 & 2,58 & 0,000 \\
Fisik & Kontrol & 40 & 2,18 & \\
\hline Respon & Intervensi & 40 & 6,80 & 0.000 \\
kognitif & Kontrol & 40 & 4,72 & \\
\hline Respon & Intervensi & 40 & 5,18 & 0.000 \\
perilaku & Kontrol & 40 & 4,30 & \\
\hline Respon & Intervensi & 40 & 4,90 & 0.000 \\
sosial & Kontrol & 40 & 2,70 & \\
\hline $\begin{array}{l}\text { Komposit } \\
\text { (Kognitif, }\end{array}$ & Kntervensi & 40 & 16,88 & 0.000 \\
$\begin{array}{l}\text { Kerilaku, } \\
\text { Sosial) }\end{array}$ & & 40 & 11,97 & \\
\hline
\end{tabular}

Tabel 4

Analisis Perbedaan Penurunan Perilaku Kekerasan Sesudah Pelaksanaan Terapi Musik Pada Kelompok Intervensi dan Kontrol di RSJD Surakarta

\begin{tabular}{lccclll}
\hline Variabel & Kelomp & $\mathrm{n}$ & Mean & SD & SE & $\begin{array}{l}\text { P } \\
\text { value }\end{array}$ \\
\hline Respon & Intervensi & 40 & 5,30 & 0,6 & 0.10 & 0,00 \\
fisik & Kontrol & 40 & 6,05 & 5 & 0.22 & 3 \\
& Selisih & & $-0,75$ & 1,4 & & \\
& & & & 0 & & \\
\hline Respon & Intervensi & 0 & 7,93 & 1,9 & 3,07 & 0,00 \\
kognitif & Kontrol & 0 & 10,28 & 4 & 3,64 & 1 \\
& Selisih & & $-2,35$ & 3,6 & & \\
& & & & 4 & & \\
\hline Respon & Intervensi & 0 & 5,35 & 0,7 & 0,12 & 0,00 \\
Perilaku & Kontrol & 0 & 7,00 & 7 & 0,40 & 0 \\
& Selisih. & & $-1,65$ & 2,5 & & \\
& & & & 2 & & \\
\hline Respon & Intervensi & 0 & 5,23 & 0,5 & 0,09 & 0,00 \\
sosial & Kontrol & 0 & 7,25 & 8 & 0,42 & 0 \\
& Selisih & & $-2,02$ & 2,6 & & \\
& & & & 7 & & \\
\hline Komposit & Intervensi & 0 & 18,50 & 2,5 & 0,40 & 0,00 \\
(Kognitif, & Kontrol & 0 & 24,28 & 1 & 1,19 & 0 \\
Perilaku, & Selisih & & $-5,78$ & 7,5 & & \\
Sosial) & & & & 5 & & \\
\hline
\end{tabular}

Perilaku Kekerasan mencakup respon fisik, kognitif, perilaku dan sosial seperti menurut Rawlins, dkk., (1993). Boyd dan Nihart, (1996) mengungkapkan karakteristik perilaku kekerasan dikaji melalui respon perilaku, sosial, kognitif dan fisik atau respon perilaku internal. Dalam bagian ini akan diuraikan pengaruh terapi musik terhadap respon fisik, respon kognitif, respon sosial, dan perilaku berdasarkan hasil penelitian yang diperoleh.

Hasil penelitian menunjukan bahwa sebelum dilakukan terapi musik hasilnya adalah setara antara kelompok yang mendapatkan terapi generalis dan terapi musik dengan kelompok yang hanya mendapat terapi generalis. Hasil rerata skor untuk respon fisik dengan skor 8,05 (tinggi) respon kognitif dengan skor 14,86 (sedang), respon perilaku dengan skor 10,91 (sedang) respon komposit dengan skor 35,81 (sedang). Hasil ini menunjukan bahwa klien berada pada perilaku kekerasan dalam katagori sedang sampai tinggi.

Menurut Rawlins, dkk., (1993) gejala yang muncul pada klien dengan perilaku kekerasan dalam respon fisik meliputi kurang dapat mengendalikan diri, ketegangan tubuh, peningkatan perilaku muka merah, pandangan, tajam, tekanan darah meningkat, nadi meningkat, pernafasan meningkat. Demikian juga dalam respon kognitif akan muncul gejala: bingung, kayalan, bantahan, menentang, ancaman verbal, merencanakan perilaku kekerasan. Pada klien dengan perilaku kekerasan akan mengalami perubahan dalam respon sosial yang mengakibatkan ketidakmampuan klien dalam melakukan hubungan interpersonal secara tepat (Boyd \& Nihart,1996). Kondisi klien menunjukan perlu penanganan segera jika 
tidak akan membahayakan bagi orang lain dan diri sendiri dan lingkungan.

Berdasarkan penurunan respon perilaku kekerasan pada kelompok yang mendapatkan terapi generalis dan terapi musik dengan kelompok yang hanya mendapatkan terapi generalis, kedua sama-sama mengalami penurunan lebih rendah secara bermakna ( $\mathrm{p}$ value 0,000). Demikian berdasarkan hasil post intervensi pada kelompok yang hanya mendapatkan terapi generalis menunjukan penurunan perilaku kekerasan dalam respon fisik skor menurun 2,18, respon kognitif skor menurun 4,72 respon perilaku skor menurun 4,30, respon sosial skor menurun 2,70, respon komposit skor menurun 11,97, Hasil ini menunjukan pada kelompok klien yang hanya mendapatkan terapi generalis mengalami penurunan perilaku kekerasan dalam katagori rendah sampai sedang.

Hal diatas membuktikan bahwa pemberian terapi generalis menurunkan perilaku kekerasan dari tinggi kesedang menjadi rendah ke sedang, seperti dalam Keliat (2003) hasil penelitian terapi generalis dengan menggunakan SAK perilaku kekerasan berpengaruh terhadap kemampuan mencegah perilaku kekerasan sebesar $86,6 \%$ dan bantuan $13,4 \%$.

Berdasarkan perbedaan selisih sebelum dan sesudah dilakukan terapi musik antara kelompok yang mendapatkan terapi generalis dan terapi musik dengan kelompok yang hanya mendapatkan terapi generalis, menunjukan pengaruh terhadap penurunan perilaku kekerasan lebih besar secara bermakna pada respon fisik $(0,40)$, kognitif $(2,02)$, perilaku $(0,88)$ dan sosial $(2,20)$. Hal ini membuktikan bahwa pemberian terapi musik menurunkan perilaku kekerasan secara bermakna.

Demikian juga berdasarkan perbedaan rerata menunjukkan adanya pengaruh terhadap penurunan perilaku kekerasan baik dalam respon fisik $(-0,75)$, kognitif $(-2,35)$, perilaku $(-1,65)$ dan sosial $(-2,02)$ serta komposit $(-5,79)$ menunjukan lebih rendah secara bermakna sesudah perlakuan antara kelompok mendapatkan terapi generalis dan terapi musik dengan kelompok yang hanya mendapatkan terapi generalis ( $p$ value $<0.005$ ).

Hasil penelitian ini sesuai dengan penelitian Gold (2007) menyatakan bahwa mengikuti terapi musik dapat lebih memperbaiki gejala pada klien Skizoprenia dibanding standar perawatan dengan total skor -9.00 dengan standart perawatan ditambah musik terapi dibanding hanya memakai standar keperawatan $(-2,96)$ dengan $\mathrm{P}=0.045)$.

Maka berdasarkan hasil diatas terapi musik dapat ditetapkan sebagai salah satu program dalam meningkatkan kualitas asuhan keperawatan jiwa, khususnya untuk klien dengan perilaku kekerasan.

Hasil analisis menunjukkan hanya jenis kelamin yang mempunyai peluang sebesar 21,7 \% terhadap pernurunan perilaku kekerasan dan pada respon kognitif merupakan peluang yang paling tinggi sebesar 25,1\% serta menunjukkan hubungan kuat $(\mathrm{R}=0,501)$. Sedangkan pada karakteristik lainnya yaitu usia, frekwensi perawatan, lama gangguan jiwa, pendidikan, pekerjaan, status perkawinan, tidak berpeluang terhadap penurunan perilaku kekerasan

Jenis kelamin berpeluang terhadap penurunan perilaku kekerasan, hal ini dikuatkan bahwa proporsi terbanyak klien 
berjenis laki-laki. Hal ini pula dapat dirasakan saat pemnelitian klien yang berjenis laki-laki lebih menggunakan kognitifnya dari pada perasaan juga mudah mengekpresikan respon perilaku pada perilaku kekerasan lebih cepat terlihat perubahannya dibandingkan klien yang berjenis perempuan.

\section{KESIMPULAN DAN SARAN}

Karakteristik klien pada umumnya berada dalam rata-rata usia 31-32 tahun, 3 kali frekwensi perawatan, lama menderita gangguan jiwa 4-5 tahun, jenis kelamin laki-laki, pendidikan SLTP-SMU, tidak bekerja dan tidak kawin. Antara kelompok intervensi dan kelompok kontrol secara statistik hasilnya menunjukan setara ( $\mathrm{p}$ value $>\alpha 0,05$ ).

Perilaku kekerasan di RSJD Surakarta sebelum dilakukan intervensi pada kelompok mendapatkan terapi generalis dan terapi musik dengan kelompok yang hanya mendapatkan terapi generalis pada alpha 5\% didapatkan adanya kesetaraan. Perilaku kekerasan di RSJD Surakarta sebelum dan sesudah dilakukan intervensi pada kelompok yang mendapatkan terapi generalis dan terapi musik dengan kelompok yang hanya mendapatkan terapi generalis, kedua sama-sama mengalami penurunan lebih rendah secara bermakna. Perbedaan selisih penurunan Perilaku kekerasan di RSJD Surakarta sebelum dan sesudah dilakukan intervensi pada kelompok mendapatkan terapi generalis dan terapi musik dengan kelompok yang hanya mendapatkan terapi generalis terdapat penurunan lebih besar secara bermakna.

Penurunan respon perilaku kekerasan di RSJD Surakarta menunjukan lebih rendah secara bermakna sesudah dilakukan intervensi antara kelompok mendapatkan terapi generalis dan terapi musik dengan kelompok yang hanya mendapatkan terapi generalis ( $\mathrm{p}$ value < $\alpha: 0.05)$.

Hubungan Terapi Musik dan jenis kelamin dengan perilaku kekerasan pada respon kognitif menunjukkan ada hubungan/ hubungan kuat $(\mathrm{R}=0,501)$. Terapi musik dan jenis kelamin mempunyai peluang sebesar $25,1 \%$ terhadap pernurunan respon kognitif.

Berdasarkan hasil penelitian diatas, maka RSJD Surakarta dapat menetapkan terapi musik sebagai salah satu program dalam meningkatkan kualitas asuhan keperawatan jiwa, khususnya untuk klien dengan perilaku kekerasan.

\section{DAFTAR RUJUKAN}

Boyd, M.A., \& Nihart, M.A. (1998). Psychiatric nursing contemporary practice, Philadelphia: Lippincott.

Gold,C. (2007). Music therapy improves symptoms in aduls hospitalised with schizophrenia evidencebased mental health, http://www. music therapy, org/factsheets/b.bpsychopathology.pdf. diperoleh 17 Maret 2009

Keliat, B.A.,(2003). Pemberdayaan klien dan keluarga dalam perawatan klien skizoprenia dengan perilaku kekerasan di Rumah Sakit Jiwa Pusat Bogor: Desertasi, Jakarta:FKM UI.

Rawlins, William \& Beek. (1993). Mental health psychiatric nursing A holistic life cycle approach. Third Edition. USA: Mosby Years Book.

RSJD Surakarta.(2008). Profil Rumah Sakit Jiwa Daerah Surakart. RSJD Surakarta. 